Vox Sang. 31 (Suppl. 1): 9-15 (1976)

\title{
In vivo and in vitro Activation of T-Antigen Receptors on Leukocytes and Platelets ${ }^{1}$
}

\author{
Judith K. Hysell, John W. Hysell, Margaret E. Nichols,
} R. G. LeONARDi and W. LaUrenCe MarSH

Blood Bank, St. Joseph Mercy Hospital, and Department of Pathology, University of Michigan Medical Center, Ann Arbor, Mich., and

Lindsley F. Kimball Research Institute, New York Blood Center, New York, N.Y.

\begin{abstract}
Serological studies on a patient whose red cells are polyagglutinable due to $T$ activation have demonstrated concomitant $T$ activity of the separated leukocytes and platelets. Normal leukocytes and platelets are not $T$ active, but activation can be induced in vitro by treatment with neuraminidase or with pneumococcus type III filtrate. Such T-active cells absorb anti-T from Arachis hypogea lectin. Tests on different types of separated leukocytes show that both neutrophils and lymphocytes have latent $T$ antigen receptors. Neuraminidase treatment of platelets does not change their ability to promote clot retraction, to aggregate with ADP, or to take up serotonin.
\end{abstract}

There is evidence that apart from the ABO blood group system [2, $6,17]$, a number of antigenic determinants are common to different types of hemopoietic cells. I and i antigens are present on leukocytes [8], the $5 b$ leukocyte antigen is present on red cells [14], and recent investigations have demonstrated that the anti-erythrocyte antibodies, anti-Kx [12], anti-U [10] and anti-Gerbich [11] can be absorbed by neutrophil leukocytes and monocytes from individuals of appropriate genotype. Within each of these last three blood-group systems other antibodies defining red-cell polymorphisms are not absorbed by leukocytes. Normal red cells, leukocytes, and platelets have also been reported to possess latent $\mathrm{T}$ antigen receptors. In vitro studies have shown that incubation of these cells with neuraminidase induces the ability to absorb anti-T from Arachis hypogea lectin [7].

1 Supported in part by grant HL09011 of the National Heart and Lung Institute, NIH.

Received: December 2, 1975; accepted: January 15, 1976. 
This report presents studies which demonstrate that in vivo $\mathrm{T}$ activation of leukocytes and platelets occurs concomitantly with $\mathrm{T}$ activation of erythrocytes. Investigation of separated neutrophils, lymphocytes, and platelets has confirmed their susceptibility to in vitro $\mathrm{T}$ activation and established that such change does not significantly impair the ability of platelets to promote clot retraction or to aggregate with ADP.

\section{Materials and Methods}

In vivo $T$ Activation

Approximately $100 \mathrm{ml}$ of blood was collected into heparin from a group $\mathrm{AB}$ patient with hemolytic anemia secondary to subhepatic abscess, in whom the red cells were $\mathrm{T}$ active. Proteus mirabiiis, Klebsiella pneumoniae, and Clostridium perfringens were cultured from the abscess at the time of operative drainage. The patient's red cells were agglutinated by $A$. hypogea lectin, which contains anti-T [3]; but not by Salvia sclarea lectin which has anti-Tn specificity, or by Salvia hormimum lectin which has both anti-Tn and anti-Cad activity [4]. The heparinized blood was centrifuged at $200 \mathrm{~g}$ for $15 \mathrm{~min}$ at $4^{\circ} \mathrm{C}$ and the supernatant plasma containing the platelets removed. The buffy coat was also removed and after resuspension in a small volume of the plasma was recentrifuged using the same parameters. The buffy coat was suspended in Hanks' solution, and anti-A,B serum that had been processed to remove anti-T, was used to agglutinate and sediment the remaining erythrocytes. The leukocyte and platelet suspensions were combined since the volume of each fraction was small. Leukocytes and platelets were prepared from blood of a healthy donor by a similar technique. The leukocyte platelet preparations from the patient and the control were each incubated with Arachis lectin at $4^{\circ} \mathrm{C}$ for $60 \mathrm{~min}$. The cells were washed four times with saline and an ether eluate prepared [15]. The eluate and, as a control, the supernatant fluid from the final saline wash were tested for activity against the polyagglutinable red cells of the patient as well as neuraminidase-treated and untreated red cells.

\section{In vitro $T$ Activation}

Buffy coats from $6 \mathrm{U}$ of centrifuged group $\mathrm{O}$ donor blood collected into acidcitrate-dextrose solution were separated, pooled, and contaminating red cells in the mixture were eliminated by the addition of dextran. The leukocyte-platelet suspension obtained was separated into its cellular components by centrifugation in a hypaque-dextran discontinuous gradient [16]. This technique yields three fractions containing predominantly neutrophils, lymphocytes, and platelets, respectively. The cell fractions were separated and washed, and an aliquot of the washed donor red cells was taken as a fourth fraction. Each of the four cell fractions was divided into three equal volumes. One volume was incubated with 4 vol of $0.05 \%$ papain solution at $37^{\circ} \mathrm{C}$ for $15 \mathrm{~min}$ and the enzyme subsequently removed by washing. The second portion of each cell fraction was incubated with an equal amount of a known $\mathrm{T}$ activating pneumococcal (type III) filtrate for $30 \mathrm{~min}$ at $37^{\circ} \mathrm{C}$, and the cells washed. 
The third portion of each cell fraction was kept as an untreated control. Each of the resulting 12-cell suspensions was packed by centrifugation and used to absorb an equal volume of Arachis lectin at $12^{\circ} \mathrm{C}$ for $60 \mathrm{~min}$. Anti-T activity was assessed by titration against $T$-active group $O$ red cells and compared with the score obtained following absorption with untreated erythrocytes. These experiments were repeated on a second series of six buffy coat cell preparations to establish the reproducibility of the results. A third series of six buffy coat preparations from group $\mathrm{O}, \mathrm{D}$-positive donors were used to absorb anti-D instead of Arachis lectin, to confirm that uptake of anti- $T$ by neuraminidase-treated leukocytes and platelets is a specific phenomenon, and to ensure that the leukocyte-platelet preparations were free of contaminating red cells or red cell stroma.

In a further study, leukocyte preparations were prepared from the blood of four donors, and pooled. Lymphocytes were isolated by hypaque-dextran discontinuous gradient centrifugation and the separated cells divided into two aliquots. One was incubated with neuraminidase at a concentration of $50 \mathrm{U} / \mathrm{ml}$ for $30 \mathrm{~min}$ at $37^{\circ} \mathrm{C}$, washed, and checked for $\mathrm{T}$ activity by using some of the cells in an absorption-elution test with Arachis lectin. The second part of the lymphocyte preparation was left untreated and used in a parallel Arachis absorption experiment as a control.

\section{Platelet Function Tests}

Blood of ten nonfasting donors who, as far as could be ascertained, had taken no medication in the previous 7 days, was collected into acid-citrate-dextrose solution. The platelets were separated by differential centrifugation in a hypaque-dextran gradient and pooled. After washing in buffered saline, the cell suspension was divided into two aliquots. One was retained as an untreated control, while the other was incubated with neuramiridase at a concentration of $50 \mathrm{U} / \mathrm{ml}$ for $30 \mathrm{~min}$ at $37^{\circ} \mathrm{C}$. Enzyme treatment was arrested by further washing and a portion of the cells checked for $\mathrm{T}$ activation by an absorption-elution test with Arachis lectin.

Platelet ${ }^{14} \mathrm{C}$-serotonin uptake and release of the enzyme-treated and control cells was investigated by the method of ZUCKER and PETERSON [18]. The aggregative response of the platelets to added epinephrine and adenosine diphosphate was measured in a chronolog platelet aggregometer. To determine clot retracting capability, treated and untreated platelets were added to platelet-poor heterologous plasma to give a final concentration of $250,000 / \mu 1$. $5 \mathrm{U}$ of thrombin were added to $2-\mathrm{ml}$ volumes of the test preparations and clot retraction measured by the method of BENTHAUS [1].

\section{Results}

\section{In vivo $T$ Activation}

Microscopic examination of the patient's leukocyte-platelet preparation revealed many neutrophils, lymphocytes, monocytes, and platelets, as well as an occasional red cell. The proportion of red cells to leukocytes 
Table I. Reactivity of Arachis hypogea lectin recovered after absorption and elution using a leukocyte-platelet preparation $\left(4^{\circ} \mathrm{C}, 15 \mathrm{~min}\right)$

\begin{tabular}{llll}
\hline $\begin{array}{l}\text { Source of leukocyte- } \\
\text { platelet preparation }\end{array}$ & \multicolumn{2}{l}{ Red cells used to test eluate } & \\
\cline { 2 - 3 } & control & T-active patient \\
\cline { 2 - 3 } & untreated & neuraminidase & \\
\hline T-active patient & 0 & 5 & 7 \\
Control & 0 & 0 & 0 \\
\hline
\end{tabular}

Table II. Titration scores [9] of Arachis hypogea lectin after absorption with enzymetreated or untreated separated cell fractions

\begin{tabular}{llll}
\hline Absorbing cells & Untreated & \multicolumn{2}{l}{ Treatment of absorbing cells } \\
\cline { 3 - 4 } & & papain & bacterial filtrate \\
\hline Neutrophils & 15 & 12 & 5 \\
Lymphocytes & 14 & 20 & 0 \\
Platelets & 19 & 23 & 0 \\
Red cells & 20 & 21 & 0 \\
\hline
\end{tabular}

Table III. Results of absorbing Arachis hypogea lectin with neuraminidase-treated and untreated lymphocytes

\begin{tabular}{|c|c|c|c|c|c|c|c|c|}
\hline & \multicolumn{7}{|c|}{ Reciprocals of dilutions of Arachis lectin } & \multirow[t]{2}{*}{ Score [9] } \\
\hline & 2 & 4 & 8 & 16 & 32 & 64 & 128 & \\
\hline $\begin{array}{l}\text { Before absorption } \\
\text { After absorption with }\end{array}$ & 12 & 12 & 12 & 7 & 6 & 3 & 0 & 52 \\
\hline $\begin{array}{l}\text { Untreated lymphocytes } \\
\text { Neuraminidase- } \\
\text { treated lymphocytes }\end{array}$ & 12 & 12 & 12 & 5 & 4 & 2 & 0 & 47 \\
\hline
\end{tabular}


was determined by direct count. Based on this ratio, sufficient $\mathrm{T}$-active red cells from the patient were added to the normal control preparation to give the same final proportion. The patient and control leukocyteplatelet preparations were then used in absorption-elution experiments with Arachis anti-T lectin. The results shown in table I, establish that the leukocyte-platelet preparation from the patient's blood had strong absorptive capacity for anti-T, while the control preparation had none. In both cases, efficiency of the final cell washing procedure was demonstrated by testing the last wash solution for anti-T activity.

\section{In vitro $T$ Activation}

Microscopic examination of the separated cellular components of the buffy coat preparations revealed the platelet fraction and the neutrophil fraction to be essentially pure, and the lymphocyte fraction to contain predominantly lymphocytes with small numbers of monocytes. Following treatment of the neutrophil preparation with papain, the cells became difficult to separate and prolonged centrifugation was necessary. The results of absorbing Arachis lectin with aliquots of the different cell fractions that had been treated with papain, with T-activating pneumococcus filtrate, or left untreated, are shown in table II. Absorption with papain-treated or untreated cells did not reduce the anti- $T$ activity of the Arachis lectin. Absorption with platelet and both leukocyte pneumococcus filtrate-treated preparations caused a significant decrease in anti$T$ activity. None of the leukocyte or platelet preparations absorbed anti$\mathrm{D}$, thus confirming that these cell fractions were not contaminated with red cells. All of the red cell preparations absorbed anti-D and as expected the red cells exposed to papain or T-activating filtrate removed more antibody than the untreated cells. Neuraminidase-treated normal lymphocytes showed strong absorptive capacity for lectin anti- $\mathrm{T}$ but untreated cells had no such capability (table III).

\section{Platelet Function Tests}

Both neuraminidase-treated and untreated platelets showed normal uptake of ${ }^{14} \mathrm{C}$-serotonin, but in neither case was it released by the addition of adenosine diphosphate (ADP) or epinephrine. Both platelet preparations gave the same low normal results in tests for aggregation following addition of ADP. Neuraminidase treatment did not affect ability of the platelets to induce clot retraction and both cell preparations gave the same normal result. 


\section{Discussion}

In vivo polyagglutinability caused by $\mathrm{T}$ activation has long been recognized as an enzymatically induced modification of red cells. It is, however, apparent that the phenomenon is in reality one of more generalized desialization that exposes latent antigen receptors in red cells, leukocytes, and platelets. It appears that the terminal neuraminyl groups which are characteristic of vertebrate blood and tissue cells [13] are attached to a common fundamental membrane structure, which, following cleavage of neuraminyl groups by neuraminidase, interacts specifically with anti-T of Arachis lectin.

Tn receptors have also been demonstrated on all cellular hemopoietic elements [7]. While patients whose red cells are polyagglutinable due to Tn activation frequently exhibit leukopenia and thrombocytopenia [5], similar changes are not typical of in vivo polyagglutination caused by $\mathrm{T}$ activation. Furthermore, while the technical procedures used in isolating platelets for in vitro $\mathrm{T}$ activation impaired their functional activity in some of the studies, the T-active platelets showed no more deficiency than did the untreated control platelets. It appears possible, therefore, that the generalized hematologic in vivo antigenic changes that are seen in $T$ activation may not affect cell functional activities.

\section{Acknowledgements}

The authors are grateful to the patient, Mr. WALTER GANTT, for his cooperation, to Ms. Frances White for assisting with the platelet function studies, and to Mr. MALCOLM BeCK for providing the bacterial filtrate.

\section{References}

1 Benthaus, J.: Ưber die Retraktion des Blutgerinnsels. Thromb. Diath. haemorrh. 3: 311 (1959).

2 Berroche, L.; Maupin, B.; Hervier, P. et Dausset, J.: Mise en évidence des antigènes $\mathrm{A}$ et $\mathrm{B}$ dans les leucocytes humains par les épreuves d'absorption et d'élution. Vox Sang. 5: 82 (1955).

3 BIRD, G. W. G.: Anti-T in peanuts. Vox Sang. 9: 748 (1964).

4 BIRD, G. W. G. and Wingham, J.: Haemagglutinins from Salvia. Vox Sang. 26: 163 (1974).

5 Dausset, J.; Moullec, J. and Bernard, J.: Acquired hemolytic anemia with poly- 
agglutinability of red cells due to a new factor present in normal human serum (anti-Tn). Blood 14: 1079 (1959).

6 Gurevitch, J. and Nelken, D.: ABO groups in blood platelets. Nature, Lond. 173: 356 (1954).

7 HICKIIN, B. and BeCK, M. L.: Latent polyagglutinable receptors on leukocytes and platelets. Abstract. Transfusion 14: 508 (1974).

8 Lalezari, P. and MurPhy, G. B.: Cold reacting leukocyte agglutinins and their significance; in Histocompatibility testing, p. 451 (Munksgaard, Copenhagen 1967).

9 MARSH, W. L.: Scoring of hemagglutination reactions. Transfusion 12: 352 (1972).

10 Marsh, W. L.; Øyen, R.; Nichols, M. E., and Charles, H.: Studies of MNSsU antigen activity of leukocytes and platelets. Transfusion 14: 462 (1974).

11 MARSH, W. L. and ØYEN, R.: Demonstration of the Gerbich antigenic determinant on neutrophil leukocytes. Vox Sang. 29: 69 (1975).

12 MARsh, W. L.; ØYeN, R.; Nichols, M. E., and ALIEN, F. H., jr.: Chronic granulomatous disease and the Kell blood groups. Br. J. Haemat. 29: 247 (1975).

13 Pardoe, G. I. and Uhlenbruck, G.: Cell surface antigens. The P and I blood group systems and some aspects of polyagglutinability. Med. Lab. Technol. 29: 351 (1972).

14 Rosenfield, R. E.; Rubinstein, P.; Lalezari, P.; Dausset, J., and Rood, J. J. VAN: Hemagglutination by human anti-leukocyte serums. Vox Sang. 13: 461 (1967).

15 RubIN, H. J.: Antibody elution from red blood cells. J. clin. Path. 16: 70 (1963).

16 Tellez, A. and Rubinstein, P.: Rapid method for separation of blood cells. Transfusion 10: 223 (1970).

17 Thomsen, O.: Untersuchungen über die serologische Gruppendifferenzierung des Organismus. Acta path. microbiol. scand. 7: 250 (1930).

18 ZUCKeR, M. G. and Peterson, J.: Effect of acetylsalicylic acid, other non-steroidal anti-inflammatory agents and dipyridamole on human blood platelets. J. Lab. clin. Med. 76: 66 (1970).

JuditH K. Hysell, Supervisor, Blood Bank, St. Joseph Mercy Hospital, 326 N. Ingalls Street, Ann Arbor, MI 48104 (USA) 